\title{
諏訪湖地域における“迷惑昆虫”ユスリカの 大発生とその防除対策
}

\author{
第 3 報：“迷惑昆虫”ユスリカの \\ 制御に関する若干の実験と防除対策への提言
}

平 林 公 男

信州大学医学部衛生学教室

\begin{abstract}
Studies on the Massive Flights of Chironomid Midges (Diptera : Chironomidae) as Nuisance Insects and Plans for their Control in the Lake Suwa Area, Central Japan 3. Some experimental trials for control of nuisance midges and proposed counterplans
\end{abstract}

Kimio Hirabayashi

Department of Hygiene, Shinshu University School of Medicine, Matsumoto

In the present paper the author tried to forecast the massive emergence of adult Tokunagayusurika akamusi midges from Lake Suwa. Furthermore, several control measures for chironomids were examined. The results obtained are as follows:

1. The forecast for the emergence of adult midges from the lake. A survey of the chironomid larva population was carried out at three stations in the lake. T. akamusi emerged at about the tenth day after the decrease of the larval number and at this time the temperature of the bottom water was within the range of $11-18^{\circ} \mathrm{C}$. The flights of adult midges were closely related to environmental factors such as air temperature, the strength and the direction of the wind and the light conditions.

2. The attraction of adult midges to lamps of various colors and wattages was studied. A comparative study on various colors of lights of the same intensity $(100 \mathrm{~W})$ showed that white was more attractive to chironomids than yellow, and that both colors were preferred to red, green, or blue. The experiment on light intensity showed that $100 \mathrm{~W}$ was more effective than $40 \mathrm{~W}$ and $20 \mathrm{~W}$ and that no differences in preference were observed between $100 \mathrm{~W}$ and $60 \mathrm{~W}$ white lamps. Therefore, the light intensity was thought to be more important than color for the control of adult midges.

3. Cyprinus is the natural enemy of the larva and pupae of T. akamusi. The total numbers of adult T. akamusi emerging from Enclosure A (in which there were 10 times as many Cyprinus as in the natural lake water), Enclosure B (no predator was present), and Station C (the natural lake) were 458, 1108, and 684 ind. $/ \mathrm{m}^{2}$, respectively. It was estimated that $38 \%$ of larvae or pupae were eaten by the fish in the lake, and by putting Cyprinus into the water, the percentage increased to $58 \%$. It seems that Cyprinus has a significant effect in reducing the number of midges in field trials.

4. The control of T. akamusi may also be achieved by employing general prevention, by physical and biological means, depending upon the nature of the breeding source, and the cooperation of inhabitants and persons concerned is necessary to carry out the control of adult midges.

5. The proposals for the control of the nuisance caused by chironomid midges are as follows:

(1) To make the inhabitants aware of the ecological role of chironomids in the lake, and the importance of protection of the natural ecosystem. Monitoring of the lake should be better organized and should be carried out regularly.

(2) Town planning which is in harmony with the environment should be proposed.

(3) The restoration and conservation of the ecosystem in the littoral zone (increases of aquatic plants, small fish, aquatic insects, etc.). 
(4) Lake Suwa and rivers flowing into it should be cleaned up to stop the progress of eutrophication of the lake.

Key words: Tokunagayusurika akamusi, Nuisance midges, Counterplans, Prediction of flights, Phototaxis, Biological control

アカムシユスリカ, 迷惑昆虫, 対策案, 発生予測, 走光性, 生物的制御

\section{はじめに}

わが国の富栄養湖沼（霞ヶ浦, 諏訪湖, 琵琶湖南湖, 児島湖，宍道湖，など）の湖底には，底生動物として大 量のユスリカ類の幼虫が生息している ${ }^{1 \sim 3)}$ 。これらの幼虫 は年に何回か羽化し，多数の成虫が湖の周辺の人家や観 光施設などをめがけて飛来し，様々な問題を引き起こし

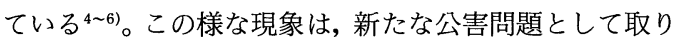
上げられ，ユスリカ類は“迷惑昆虫 (Nuisance Insects)” と称されて，地域住民に嫌われている7。また，近年で は，ユスリカ類が気管支喘息のアレルゲンとなることも 指摘され，医学的にも注目されている ${ }^{8 \sim 12) 。 ~}$

ユスリカ類の大量発生に対しては，その制御に関する 多くの研究がなされておりり ${ }^{13 \sim 15)}, \mathrm{Ali}^{16)}$, Tabaru et al. ${ }^{17)}$ による詳細かつ総合的な総説がある。従来の研究は物理 的な制御をはじめとして，化学物質による方法，生物的 な捕食関係による方法などが挙げられるが，中でも殺虫 剤を用いた化学的防除が効果的であるとされており ${ }^{18,199}$, 都市河川 ${ }^{20,21)}$, 養魚池 ${ }^{22,23)}$, 下水処理場 ${ }^{24,25)}$ などユスリカ 発生源の比較的限定された地域においては, 有効性が認 められている。しかし, この様な化学薬品を用いた防除 は, 対象範囲が広い自然湖沼などにおいては効果が期待 できず，また，他の生物種への影響が懸念されたり，薬 剤抵抗性の獲得など, 様々な問題を抱えている ${ }^{16,17)}$ 。ま た，生物的方法としての魚類による捕食に関しては，い くつかの魚種で研究されており, 限定された水域での有 効性は認められているが，これについても他生物への影 響などの問題が指摘されている ${ }^{16)}$ 。したがって, 防除範囲 の広い止水域におけるユスリカ対策に関する研究は, 近 年までほとんど例がなく ${ }^{26)}$ ，その対策も目途が立ってい ないのが現状である。

本研究では, すでに第 1 報27で, ユスリカ大発生に関 して, 湖内の幼虫分布, 湖からの成虫発生量, 飛翔時間 帯, 飛翔範囲, 等を明らかにし, また, 第 2 報28) では, 湖周辺地域に住む住民のユスリカ問題に対する意識構造, ならびに具体的な被害の実態をアンケート調査によって 明らかにした。
本報告は, これらの前報の結果を基に自然湖沼におけ るユスリカ対策を提案しようとするものであり, 現場で の制御に関する若干の実験を行い防除対策を検討した。 具体的には成虫の被害を未然に防ぎ, 上り効果的に防除 を行うための発生予知の試み, 飛来成虫については走光 性に関する誘引実験を行い光による誘導を検討し, 幼虫 については湖内での生物的制御の効果を調查し, 捕食者 である魚類（コイ）の役割を検討した。

\section{材 料 - 方 法}

調查地域である諏訪湖, およびその周辺地域の概況に

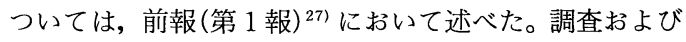
実験の対象としてはアカムシユスリカ (Tokunagayusur ika akamusi）を主としたが，これについても前報に詳述 した。調查および実験の期間は1989年 9 月26日から 11 月 9 日までの 45 日間である。

1. 湖からの成虫発生予知

（1）底泥中のユスリカ 4 齢幼虫および蛹の個体数

成虫発生予知のため, 底泥中のユスリカ 4 齢幼虫と蛹 の個体数変動を調査した。諏訪湖湖心から東岸にかけて の直線上に位置する水深 $6 \mathrm{~m}, 4 \mathrm{~m}, 2.5 \mathrm{~m}$ の 3 地点で底 泥の採集を行った (Fig. 1)。Ekman-Birge 採泥器 (採集 面積 $15 \times 15 \mathrm{~cm}^{2}$, 約 $10 \mathrm{~cm}$ の深さまで採泥できる）によ り，1 地点につき 3 回の採泥を行い, ネット(NGG54： メッシュサイズ $0.33 \mathrm{~mm}$ ) で泥を除き, ネット内に残さ れた試料を 1 回分ずつポリ袋に入れた。試料は実験室に 持ち帰り，直ちに幼虫と蛹を種類ごとに選別し個体数を 測定した。各地点の底泥表層水温は自記温度計（離合社, RMT）により，調査期間中，20分間隔で測定した。

（2）湖底からの成虫羽化量

測定場所は, 前記幼虫の採集地点と同じであり, 底泥 表面に設置する湖底式エマージェンストラップ（福原： 1970の改良型27)）を用いた。採集日ごとに, 羽化成虫, 蛹, 脱皮殼を回収し, 実験室に持ち帰り個体数を調べ, 成虫と蛹の合計を羽化量とした。

（3）湖岸における成虫飛来量

ライトトラップによる捕獲成虫数と, 成虫の壁面にお 


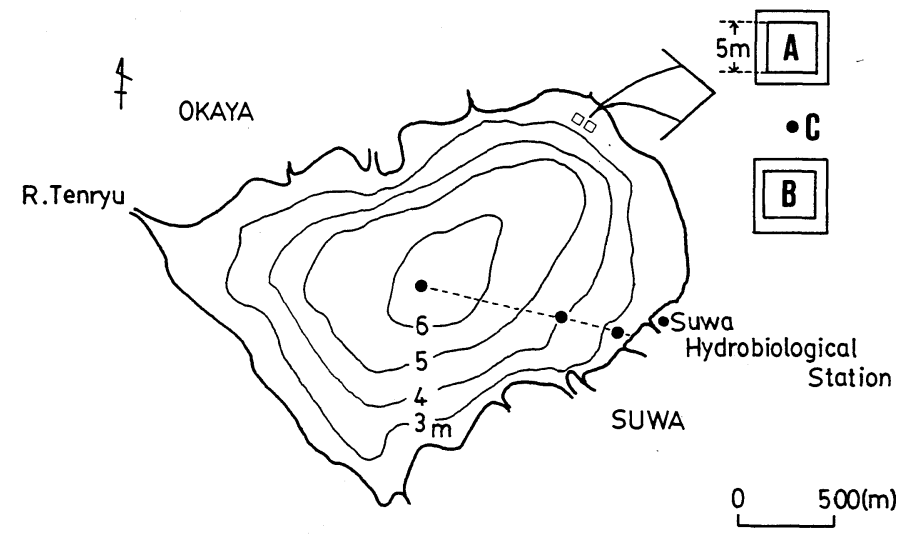

Fig. 1 The sites of emergence trap experiments (black circles) and predation experiments (A, B, C) using floating nets in Lake Suwa.

ける休息個体数の測定を行った。調査は東岸に位置する 信州大学理学部附属諏訪臨湖実験所 (以後, 臨湖実験所) にて，毎日行った。

a) ライトトラップによる成虫飛来量

$6 \mathrm{~W}$ のブラックライトの付いたライトトラップ (SEIDENKO 電気捕虫機 CL-206N) を, 臨湖実験所の敷 地内（地上 $1.5 \mathrm{~m}$ ) に設置し, 夕方 $16: 00$ から翌朝の 7 ： 00 までの15時間点灯した後回収した。

b ）壁面に休息している成虫個体数の変動

臨湖実験所の建物の壁面（白色）に休息（resting）し ているユスリカ成虫の個体数を調査期間中, 毎朝 $6: 00$ (日の出前)に測定した。測定したコドラートの大きさは $1.62 \mathrm{~m}^{2}(1.8 \mathrm{~m} \times 0.9 \mathrm{~m})$, 材質はコンクリートで, 降雨 は屋根により遮られている。なお, 気象条件として, 1 日の積算降雨量, $19: 00$ 気温 $\left({ }^{\circ} \mathrm{C}\right)$ を毎日, 臨湖実験 所にて観測した。

\section{2. 野外における人工光源による成虫誘引実験}

実験は臨湖実験所の屋上（地上約 $18 \mathrm{~m}$ ) において，9 月29日から10月 7 日まで行った。ライトトラップ 5 機を 用い, 色拉よ゙ワット数 (照度) の異なる電球の光（可 視光領域に限定）に対する走性を調べた。トラップの配 置を Fig. 2 に示した。中心 (St. 1) に常に基準となる 100 $\mathrm{W}$ の白色光電球 (以下 $\mathrm{W}-100$ と呼ぶ) の付いたトラップ を設置し,それを中心にして約 $11 \mathrm{~m}$ 離れた 4 ヶ所(St. 2 〜 5 ) にトラップを設置した。St. 2-3，4-5の距離は約 9 m, St. 2-5，3-4 の距離は約17.5 m である。また, St. 2 〜 側は湖岸に, St. 4 5 側は流入河川の衣之渡川に面 している。トラップの吸入口から床までは50 cm, 電球の

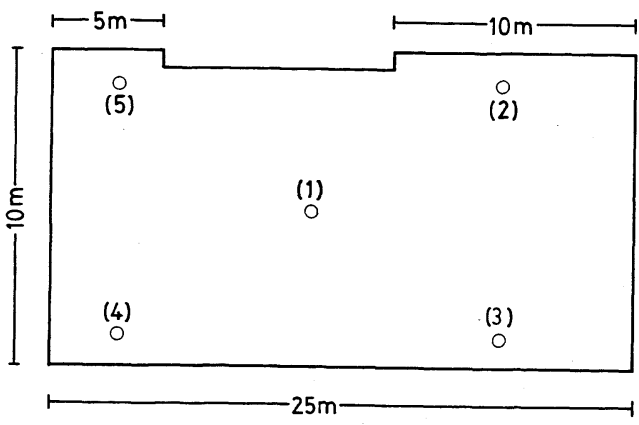

Fig. 2 Arrangement of light traps on the rooftop (18 $\mathrm{m} \mathrm{high)} \mathrm{of} \mathrm{Suwa} \mathrm{Hydrobiological} \mathrm{Station.} \mathrm{At}$ position (1) trap with white $100 \mathrm{~W}$ bulb was always set as a standard, and at positions (2) to (5) experimental traps with four different kinds of bulbs were set and rotated in turn.

中心から床までは60 cm の距離がある。吸入口から電球 までは水平方向に約 $30 \mathrm{~cm}$ 離れている。各々の設置位置 の不平等をなくすために, 基準となる St. 1 を中心に毎 日，各トラップをSt. 2 から St. 5 へと順次ずらし，4 日 間で 1 シリーズの実験終了とした。なお周辺部には実験 に影響を及ぼすような強力な光源はなかった。

光の色については $100 \mathrm{~W}$ の白色 (W-100), 黄色 (Y$100)$, 青色 (B-100), 緑色 (G-100), 赤色 (R-100) 電 球を用いて実験を行った。各電球の波長は, 白色の 100 $\mathrm{V}, 40 \mathrm{~W}$ の電球との比エネルギーとして Fig. 3 に示し た。

照度については, ワット数の異なる白色の電球, $100 \mathrm{~W}$ 


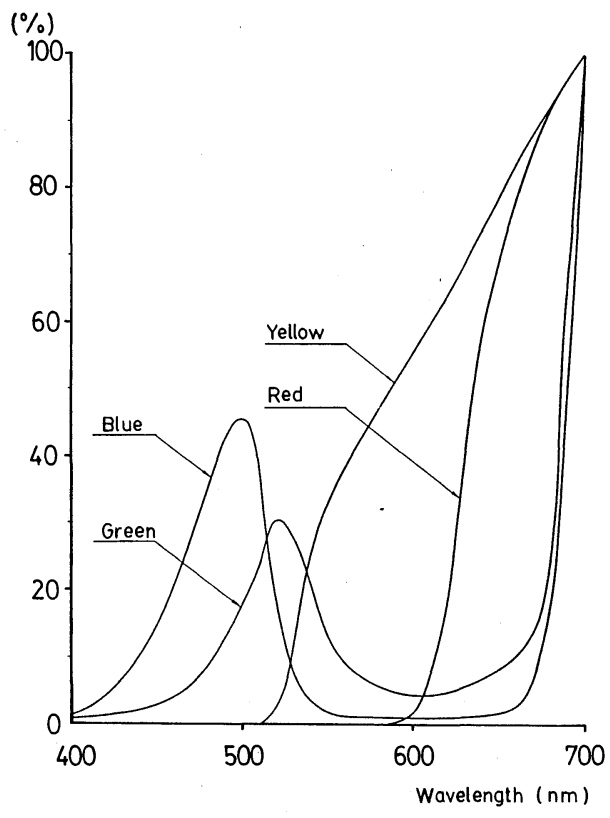

Fig. 3 Distribution of relative spectroscopic energy of the bulbs which were used for light induced experiments. The energy of the white $40 \mathrm{~W}$ bulb $(100 \mathrm{~V})$ was calculated as $100 \%$. Cited from Toshiba Lighting \& Technology Co. "Technical Data".

$(\mathrm{W}-100), 60 \mathrm{~W}(\mathrm{~W}-60), 40 \mathrm{~W}(\mathrm{~W}-40), 20 \mathrm{~W}(\mathrm{~W}-20)$ を用いた。使用した各電球の照度は, 照度計(東芝 5 号) を用いて, 電球下 $(60 \mathrm{~cm})$ で測定した。その結果, W100は474, W-60は251,W-40は171, W-20は52.5Lux で あった。

実験時間は日没時から翌日の日の出までとし, 回収は 毎朝 6:00に行った。試料は殺虫剤で処理した後, すぐ に実験室に持ち㷌り, 白色バット上にあけ, 肉眼で種類 ごとに雌雄の別に分類し, 個体数と湿重を測定した。な お, 個体数が多い場合には, 試料の総重量を測定し, そ の中から三回の標本抽出を行い総個体数を推定した。

\section{3．魚によるユスリカ幼虫捕食実験}

実験は1989年10月 7 日から10月30日まで行った。湖内 の水深 $2.5 \mathrm{~m}$ の地点 (Fig. 1) に面積 $5 \times 5 \mathrm{~m}^{2}$, 深さ $2.5 \mathrm{~m}$ の「網いけす」を 2 基（A， B ）設置した。「網いけす」 は四方を網（網目約 $0.9 \mathrm{~cm}$ ）で囲ったもので, 底張りは 無く, 魚は底泥に接触できる状態になっている。実験区 $\mathrm{A} に$ は, 平均体重 $407.3 \mathrm{~g}$ のコイ (Cyprinus sp.」20尾を 入れた。この密度は, 諏訪湖における推定密度の約 10 倍
に相当する。実験区Bには，魚を入れず対照区とした。 「いけす」外に比較のための実験区Cを設けた。各実験区 の水面には, ユスリカ羽化成虫を捕獲するために, 面積 $1 \mathrm{~m} \times 1 \mathrm{~m}$, 高さ $1 \mathrm{~m}$ のかや状の羽化トラップを, 下端が 水面下約 $50 \mathrm{~cm}$ まで水没するように設置し，1〜2 日ご とに成虫の羽化数を測定した。なお，予備調査により， 「いけす」設置地点付近の幼虫数がほぼ一定であることを 確認した。

\section{結果}

1. 降雨量および底泥表層水温の変化

調査期間中における一日毎の積算降雨量と, 湖心（水 深 $6 \mathrm{~m}), 2.5 \mathrm{~m}$ 地点の自記温度計による底泥表層水温の 変化を Fig. 4 に示した。湖心部では，9月29日には $18^{\circ} \mathrm{C}$ を越えていたが，それ以降は徐々に低下し，10月9日に は $13^{\circ} \mathrm{C}$ まで急激に下がった。この低下は, 降雨と一致し ている。12日から17日にかけて明らかな上昇を示したが, 18日から19日にかけと再び降雨の結果とも思われる急激 な低下がみられた。その後は，不規則な高低を示したが 10 月 31 日には $11^{\circ} \mathrm{C}$ で低下した。2.5 m 地点では, 湖心に 比べ水温の変化が激しいが, 基本的な変動のパターンは 同じであった。10月9日，18日，24日に見られる急激な 水温の低下は, いずれも降雨と合致し, また，10月30日

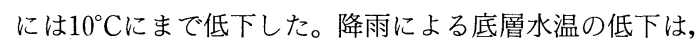
湖心と $2.5 \mathrm{~m}$ 地点で比較してみると, 水深の浅い $2.5 \mathrm{~m}$ 地点の方が顕著に現れていた。

2. 4 歯幼虫, 蛹, 成虫（羽化および飛来成虫）の個体 数変動と気温

Fig. 5 に 4 齢幼虫, 蛹, ならびに成虫(羽化および飛来 成虫）の個体数変動と $19 ： 000$ 気温の変化を示した。な お, 羽化成虫, 蛹, 4 歯幼虫の個体数は, 湖内 3 地点の 平均值で示した。

19:00の気温は, 10 月 6 日までは $15^{\circ} \mathrm{C}$ 前後を変動して いたが, 7 〜1日の期間は $10^{\circ} \mathrm{C}$ 前後まで下がった。12〜16 日までは再び $15^{\circ} \mathrm{C}$ 前後を変動したが 17 日には $6.6^{\circ} \mathrm{C}$, 調 查期間中, 最低気温を示した。その後, $10 \sim 15^{\circ} \mathrm{C}$ の間を 変動し,下降の傾向を示した。

4 齢幼虫の個体数は, 10 月上旬まで, 350 個体 $/ \mathrm{m}^{2}$ 前後 を変動し, 10 月 6 日には395個体 $/ \mathrm{m}^{2}$ であった。それ以後 個体数は急激に減少し, 10 月 24 日には44個体 $/ \mathrm{m}^{2}$ と最小 值を示した。蛹数は 4 齢幼虫の減少に対応して増加し, 10月12日から18日にかけて99個体が捕獲された。蛹数は 4 齢幼虫のピークから 6 日後の10月12日にピークを示し, さらに, 羽化成虫数はそれから 4 日後の10月16日に64個 
$\lceil 680]$

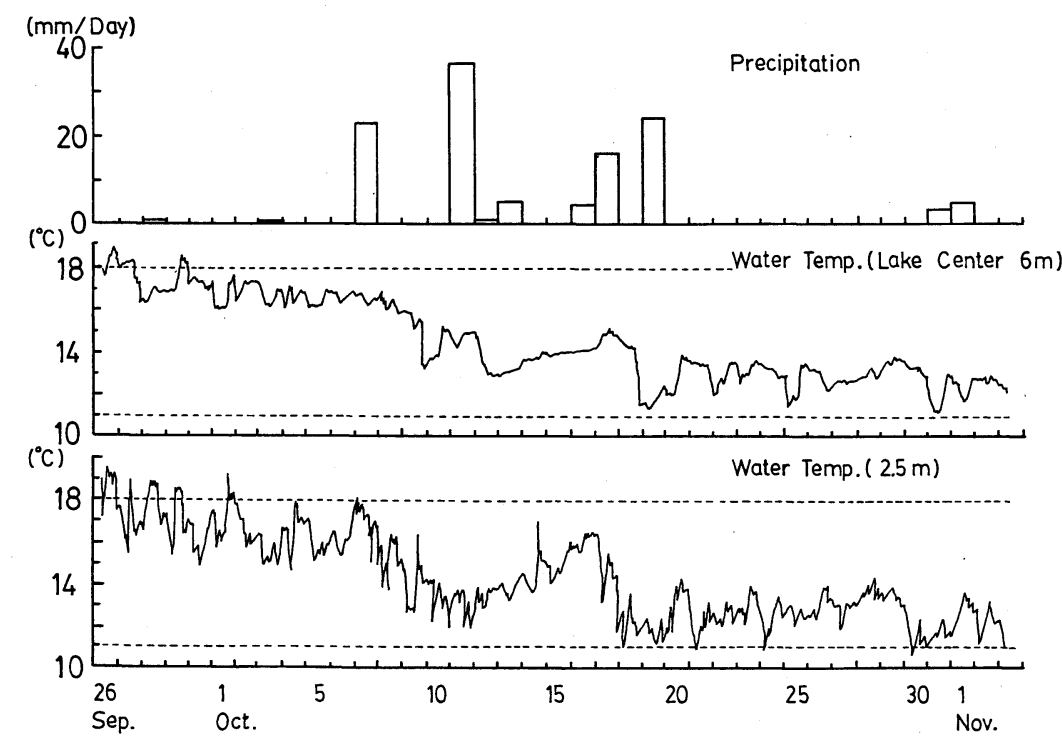

Fig. 4 Changes of daily precipitation ( $\mathrm{mm} / \mathrm{day}$ ) and the water temperature at the bottom of the two experimental sites : the central point of the lake, $6.0 \mathrm{~m}$ deep, and another point $2.5 \mathrm{~m}$ in depth from 26 September to 3 November, 1989.

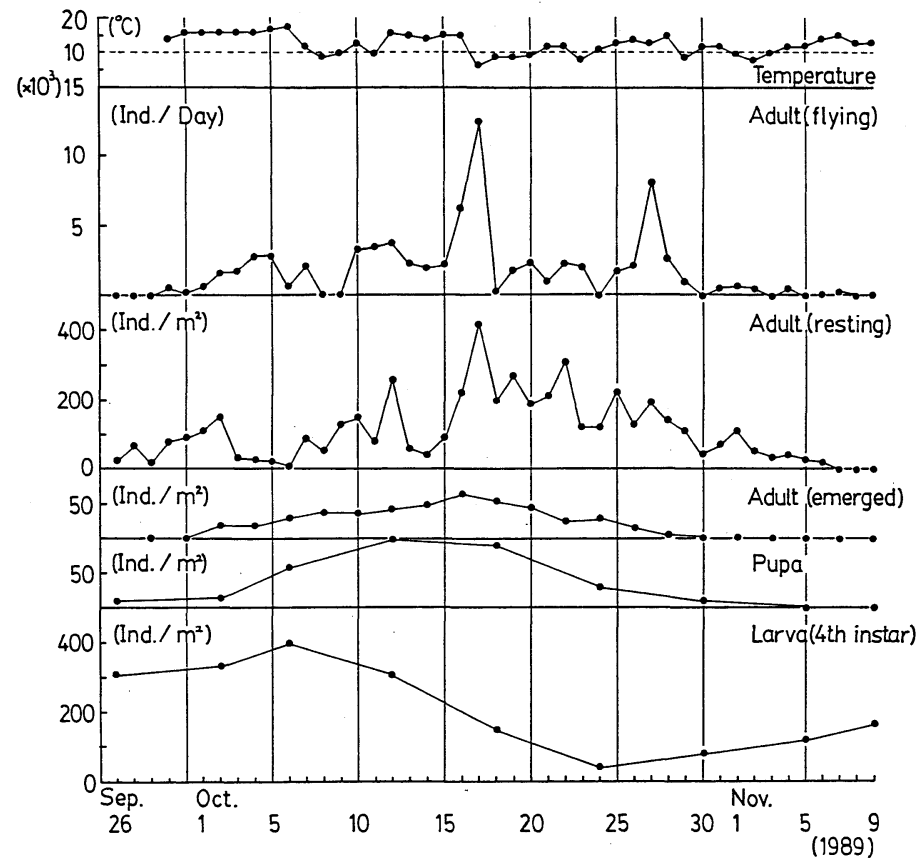

Fig. 5 Changes in the numbers of pupae and fourth instar larvae in the sediment, adults emerging from the sediment, adults resting on the wall, and adults flying (by light trap), and air temperature at $19: 00$ from 26 September to 9 November, 1989. 
平林：諏訪湖地域における“迷惑昆虫”ユスリカの大発生とその防除対策

第 3 報: “迷惑昆虫”ユスリカの制御に関する若干の実験と防除対策の提言

体 $/ \mathrm{m}^{2}$ のピークを示した。ここで, 10月 6 日の 4 齢幼虫の 個体数（395）を $100 \%$ とすると，その内の $25.1 \%$ が泥上 で蛹となり，蛹個体数の $64.6 \%$ が成虫となることが推計 された。以上のことより，4 齢幼虫から蛹を経て, 羽化 する時間的過程と湖底からの発生量が明らかとなった。

飛来成虫数は，ライトトラップによる捕獲個体数と， 湖岸にある建物の壁上に resting している個体数とを示 した。このいずれもが10月17日にピークを示し，先に述 べた 4 齢幼虫, 蛹, 羽化成虫の個体数のピークに対応す るものと考えられる。湖からの羽化が観察されなくなっ た 11 月 5 日以後， 6 日間は飛来成虫が捕獲または観察さ

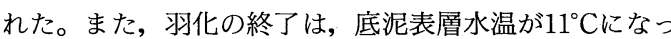
た時期と一致していた。

\section{3 ．光によるユスリカ成虫の誘引実験}

異なった色，あるいは異なったワット数（照度）の電 球に誘引された成虫個体数（全捕獲数に対する各色ある いは各ワット数の電球に集まった成虫捕獲数の割合）を Fig. 6, および Fig. 7 に示した。Fig. 7 には照度もあわせ て示した。

まず，Fig. 6 に示した色との関係についてみると，W100 (照度474 Lux）で，最も多くの成虫が捕獲された。 これに次いで $\mathrm{Y}-100$ が多くの成虫を誘引しているが，こ の照度は W-100に次いで高く, $261 \mathrm{Lux}$ であった。これ らの他は，いずれも成虫捕獲数が少ない傾向を示した。

Fig. 7 は白色光を用いて行った照度との関係について の実験結果である。W-100 は，W-40，W-20 に比べてよ り効果的にユスリカ成虫を誘引していることがわかる。 ただし, W-100 と W-60 とは, 成虫捕獲数に有意な差が 認められなかった。

\section{4. 魚による捕食の効果}

コイを用いた実験の結果を Fig. 8 に示した。実験区 $\mathrm{A}$ に入れたコイの密度は, 諏訪湖において推定されている コイの密度の10倍に相当する。いずれの実験区において も, 実験期間中の羽化個体数の変動パターンは類似して いた。

捕食者の少ない実験区 B（対照区）における成虫羽化 量は, 他の実験区に比べ明らかに多く, 捕食圧の差を示 している。実験区Bでは, 10月19日に最大羽化数151個体/

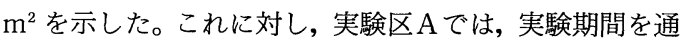

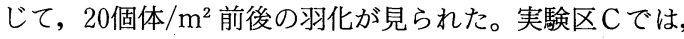
実験区 $\mathrm{A}$ と Bの中間の值を常に示していた。

実験期間中の羽化成虫の積算個体数は，捕食者である コイの存在する実験区 $\mathrm{A} て ゙ は 458$ 個体 $/ \mathrm{m}^{2}$, コイを除いた 実験区Bでは1108個体 $/ \mathrm{m}^{2}$ ，いけすの外側である実験区
$\mathrm{C}$ では684個体 $/ \mathrm{m}^{2}$ となり, 実験区 $\mathrm{A}$ と B, 実験区 B と C との間では, 有意差 $(p<0.01)$ が認められた。以上のこ とから，コイにより羽化途中のユスリカの約 $58 \%$ が捕食 されたと推定された。

考察

1．ユスリカ成虫大量発生予知の可能性

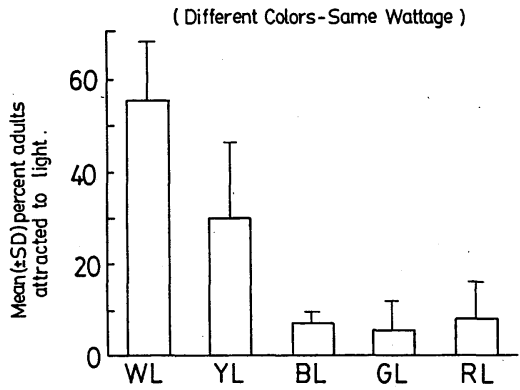

Fig. 6 Attraction of adult Tokunagayusurika akamusi to five different colors with the same wattage $(100 \mathrm{~V})$ tested in the field. The bars represent the percentages of adults attracted to light. ; W $\mathrm{Y}, \mathrm{B}, \mathrm{G}$, and $\mathrm{R}$ indicate white, yellow, blue, green, and red incandescent lamps, respectively.

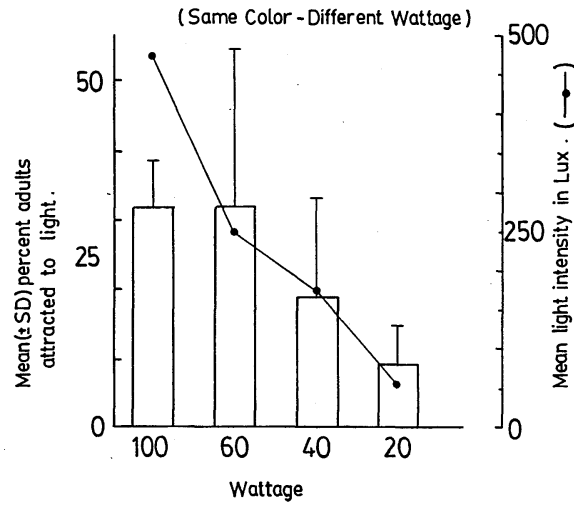

Fig. 7 Attraction of adult Tokunagayusurika akamusi to four different lights of the same colors but different wattages tested in the field. The bars represent the percentages of adults attracted to white light while the line graphs indicate the light intensities. ; $100-\mathrm{W}, 60-\mathrm{W}, 40-\mathrm{W}$, and $20-\mathrm{W}$ indicate white incandescent lamps 100 watts, 60 watts, 40 watts, and 20 watts, respectively. 


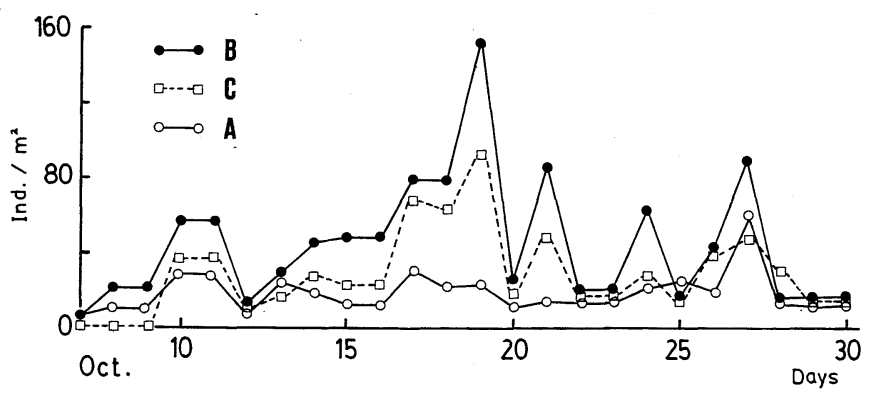

Fig. 8 Predation experiment by carp in enclosed $0.5 \mathrm{~mm}$ mesh nets. A : Enclosure with 20 carps of about $400 \mathrm{~g}$ weight each. B : Enclosure in which no carp were included. C: Not enclosed.

ユスリカ被害を未然に防ぐためには，成虫の大量飛来 を予知する事が不可欠である。本研究により，成虫の大 量発生の時期，ならびに発生量の予知は，生物学的な発 生段階を継続的に追跡調查することによって可能である ことが明らかとなった。

すなわち，生物学的発生段階の各ステージの時間的関 係は，4 齢幼虫数が減少し始め, 蛹の数がピークに達す るまでに約 6 日間を要し，その 4 日後に底泥からの羽化 成虫のピークがあることが解明された（Fig. 5)。換言す ると，4 齢幼虫の個体数のピークから約 10 日後に湖岸地 域で成虫の大量飛来が予測されることになる。

飛来との関係については, 羽化量が多ければ飛来量も 多くなることは明らかである。しかし，羽化が始まった 後に, 飛来成虫がほとんど確認されなくなった10月18, 19日は，何れも近日に降雨があり，水温も急激に低下し ている期間であった。また，飛翔時間帯の気温も17日に は調査期間中, 最低を示した (Fig. 5)。山岸ら ${ }^{299}$ は $C$. plumosus 成虫について, 飛翔時間帯の気温が $10^{\circ} \mathrm{C}$ を割る と，成虫飛翔量が少なくなることを報告している。これ らの日の飛来成虫の少ない要因については，降雨，降雨 による底層水温の低下，あるいは飛翔時間帯の気温の低 下，等が考えられる。

T. akamusi 幼虫は, 夏期の水温の高い時期に底泥の深 部に潜って夏眠する事が知られている2)。そして, 水温が 下がる秋期に底泥表面に出てきて羽化する。つまり，比 較的低温に適応した種であることが報告されている300。 よって，他のユスリカ類よりも低い水温で羽化が始まる。 底泥加の羽化は, 底層水温に依存して起こり, 今回の 調査では $18^{\circ} \mathrm{C}$ 放化が始まり $11^{\circ} \mathrm{C} て ゙$ 終了した（Fig. 4, Fig. 5)。これは岩熊ら ${ }^{31)}$ が霞ヶ浦，および諏訪湖の $T$. akamusi の羽化と水温についての報告結果に良く一致 している。10月17日ならびに27日の成虫大量飛来（大量
羽化）と水温との関係を見ると，12〜16日，あるいは 24〜26日にかけて2.5 m 地点では水温の急激な上昇が観 察された (Fig. 4)。この急激な水温上昇が, 発生段階に おける有効積算温度と関係し, 大量発生の引き金になっ たと推察される。

どこに飛来するかについては，第 1 報27) に示したよう に, 風や光との関係が無視できない。風向, 風速ならび に, 光の配置により飛来量が決定されると考元られる。

以上を総合すると, 成虫羽化注層水温に依存してお り, 飛来成虫数は飛翔時間帯の気温, 風, 光の配置など の湖水外の条件に大きく影響されると考えられる。

ユスリカによる “Nuisance” の問題は, 湖からの発生 量（=羽化量）をコントロールするか，または，飛来の 状況をコントロールするのかの何れかで解決は可能であ ると考えられる。以下，この 2 点について考察をする。 2 . 羽化量のコントロール

従来の研究では, 有機リン系の殺虫剤（テメフォス ${ }^{21)}$ ほか), ならびに幼若ホルモン系の IGR 剤 ${ }^{32,33)}$ (デミリン ほか）などの化学物質の散布による方法が有効であると されてきた。都市河川や養鰻池などの比較的小規模な水 域についての実施例が報告されている ${ }^{18 \sim 23)}$ 。しかし，こ うした化学的防除を自然湖沼のような限定されない水域 に適用することは，湖沼生態系の攪乱を引き起こすこと や, 薬剤の残留性の問題, さらには, 経済的な問題など 様々な問題点があり, 安易に実施できない ${ }^{16,17)}$ 。近年, 微 生物 (Bacillus thuringiensis) ${ }^{34)}$ の産する殺虫性の結晶 タンパクを用いてユスリカ駆除をする試みが進められて いるが，研究途上にある ${ }^{35 \sim 37 \text { 。 }}$

自然湖沼の様な水域において, 最も可能な方法として, 生物的防除が考えられる。生物防除関する研究では, ウイルス, 系状菌, 線虫などの生物がユスリカの天敵と して報告されているが，防除の効率やその効果などから 
魚類を用いた研究報告例が多い ${ }^{16,17)}$ 。

岩熊ら ${ }^{38 \sim 40)}$ は, 諏訪湖において隔離水界を用い, 実験 的にカワチブナ (Carassius cuvieri) やコレゴヌス (Coregonus lavaretus) 等の魚類を投入し，ユスリカ幼虫 の変動とその羽化量について検討している。その結果, 魚種によってその捕食量, 捕食時期が異なる事を報告し ている。

本研究では諏訪湖での在来種でもあるコイ (Cyprinus) を用いて, その捕食効果についての検討を行 つた。コイによる捕食圧を除いた実験区 B に対し，高密

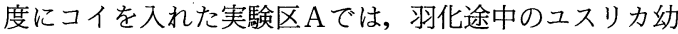
虫あるいは蛹の約 $58 \%$ が捕食されることが明らかとなっ た。さらに，網いけすの外側，すなわち，天然魚の存在 する湖内においては約 $38 \%$ が捕食されており，生物的防 除が現状でも有効に機能していることが明らかとなった (Fig. 8)。しかし, 平出・沖野 ${ }^{41)}$ が1983年に諏訪湖内で推 定した魚類によるユスリカの捕食量は $50.8 \%$ で，今回の 天然魚による捕食の割合はそれを大幅に下回った。この 理由として，ユスリカに対する捕食者の位置にあるワカ サギ (Hypomesus olidus), コイ (Cyprinus), フナ (Carassius)などの魚類の生息数が, 近年, 急激に低下し ていることが推測される。これは, 諏訪湖の漁獲量が, 1975年までは約 $450 \mathrm{t}$ 程度あったものが, 1976年から82年 には約 $300 \mathrm{t}$ に減少し, 近年では $170 \mathrm{t}$ 前後にまで減少し ていることからも理解できる。とくに，ワカサギの漁獲 高の減少が大きく影響を及ぼしている（長野県水産試験 場資料)。この原因として, 護岸工事による沿岸帯(水草 帯) 破壊による魚類の生息場所や産卵場所の減少などが 影響を与えていると推察される。以上のことからユスリ 力成虫の大発生を制御する要因の一つとして天敵魚の役 割を考慮する必要がある。すなわち，湖における魚類の 生息場所や産卵場所の回復が急務であることを意味する。 3 . 成虫に対する防除法の検討

光に誘引される昆虫についての研究は数多くあり, 昆 虫の種類や光の波長域によって, 誘引反応行動には様々 な場合がある。一般に夜行性の昆虫の多くは，300-390 $\mathrm{nm}$ の近紫外光領域に反応特性を持つものが多( ${ }^{42)}$ 。し かし, 蚊のAedes aegypti は赤外領域近くにその誘引波 長を持っていることが報告されている(3)。この様に昆虫 の種類・グループ間で異なった反応特性を持つ事が知ら れている44-46)。

近年問題となっているユスリカ類について, Belton et al. ${ }^{47)}$ は, 成虫が光に誘引されることを報告している。Ali et al. ${ }^{48,49)}$ は, 湖沼から発生した成虫（Glyptotendipes paripes, Goeldichironomus holoprasinus, Chironomus crassicaudatus, Tanypodinae, etc.) を光によってコント ロールするための室内実験，ならびに野外実験を検討し， ユスリカ成虫を集合させる重要な要因として,光の量(明 るさ, 照度), 光の質 (色彩, 波長), 発光源の種類, な どを挙げている。この中で, 最も重要な要因として光の 量を指摘しているが，ユスリカ類の種類によってその誘 引性に大きな違いのあることを同時に示している。

羽化したユスリカ成虫は，第 1 報 27 で述べたように， 光に誘引されて人家や観光施設に飛来し, “Nuisance”な 昆虫となる。本報告ではさらに，実験的に誘引の状況が 変化するかについて検討を行ったが, T. akamusi の場合 には，可視光領域においては光の色にあまり関係がなく， 光の強さ (照度) によってより効果的に誘引されること が明らかとなった(Fig. 6, Fig. 7)。このことは, 第 1 報 ${ }^{27)}$ の飛来範囲の検討結果からも明らかになっており, 強光 を発する施設の存在が成虫飛来の範囲を広げていた。す なわち, 湖周辺地域の無統制な光の配置がユスリカの飛 翔行動を乱し, 飛来密度を不均一化させ “迷惑昆虫”を 顕在化していると考えられる。これらの結果は, Ali et al. ${ }^{48,49)}$ の実験結果とも良く一致している。以上のことを 総合すると, 適切な光の量, 質の配置によりユスリカ成 虫を誘導することは可能であると考えられる。

4. 湖沼におけるユスリカ対策への提言

（1）住民の生活上の対策

地域住民のユスリカに対する被害感は第 2 報 ${ }^{28)}$ で述 ベた様に，成虫の大量飛来に伴う「洗濯物や壁が污れる」 「食べ物に入る」などの生活に密着した“Nuisance”を訴 えている。住民の生活上における自衛策としては，成虫 飛来を減少させるために,「飛翔時間帯における電灯の照 度を落とす」「網戸を付ける」「厚手のカーテンを付ける」 などが挙げられる。この様な個人レベルでの対応から発 展し, 諏訪湖湖水, 底泥の浄化がユスリカ発生を抑える 根本的な方策であることを理解し，日頃から家庭雑排水 の量を減らすように心掛けたり, 積極的な湖の管理, 保 全のための地域活動への参加が期待される。

（2）地域住民に対する啓蒙活動

ユスリカ問題の起こっている水域の周辺においては, とかくユスリカ類の迷惑側面のみに注目が集まってしま う。しかし, 湖沼生態系におけるユスリカ類の役割は非 常に重要であり, 湖底に堆積した有機物の分解や, 湖外 への持ち出しによる湖の浄化機能は大きい ${ }^{50)}$ 。こうした ユスリカ類の益虫としての側面と迷惑昆虫としての両側 面を理解した上で，生態系のバランスを取りながら防除 
を遂行していかなくてはならない。今後，益虫としての 側面を地域住民に対してアピールしていくことも大切で あり，また，こうした研究成果を地域住民の意識に移転 し，地域保全に導入していく啓蒙活動 ${ }^{51)}$ が今後の環境衛 生の分野でも重要となってくると思われる。

（3）発生状況の予知と予報

発生状況の予知を行うにあたり，関係諸機関，研究者 による継続的な調查を組織的に行うことが大切である。 ユスリカ幼虫数から発生量を, 生物的発生段階と底層水 温から発生時期を予知し, 協議し判断して, 地域住民に 対して逐次情報を伝達し, 対応を決めていくことが重要 である。

（4）町づくりと湖沼生態系への配慮

諏訪湖から発生するユスリカの問題を解決するために は，湖のみならず，その周辺地域をも含めた総合的な対 策を考えて行かなくてはならない。周辺地域においては, ユスリカ成虫の飛来を適当な方向へ誘導するように，光 の性質, 方向, 強さなどに配慮し, 街路樹による遮光や その配置なども含めた環境整備が必要である。また，湖 内においては，天敵魚の計画的養殖による生物的コント ロール，幼虫の餌となる有機物総量の削減，魚類等の捕 食者 (小魚, 水生昆虫, 小鳥など) の生活（産卵，採餌） 場所の確保，水草帯復活に代表される水中一陸上間のバ ッファー的空間としての沿岸生態系の回復, 整備, など が重要である。この様に，ユスリカ対策を遂行するにあ たり，地域の町づくりと湖沼生態系への配慮が十分に必 要であると考える。今，まさに自然環境と調和した人間 活動の在り方を模索して行かなくてはならない時期にき ているといえよう。

$$
\text { 結 論 }
$$

自然湖沼におけるユスリカの大量発生についての対策 を検討するために，諏訪湖とその周辺地域をモデルとし て, 湖からの成虫羽化量と周辺地域への成虫飛来の予知 の試み，成虫および幼虫の制御に関する実験的検討を試 みた。以下に，得られた結果を列挙する。

1. 湖内における幼虫・蛹の個体数, および习习习化量の 変動から, 成虫発生の予知が可能であることが明らかと なった。すなわち, 幼虫の減少, 蛹の出現が始まってか ら，10日前後に，湖からの成虫羽化はピークとなる。主 な羽化要因は底層水温であり, 飛来には, 気温, 風, 光 の配置などの要因が関与する。

2. ユスリカ成虫の制御実験として, 光に対する誘引 実験を行った。可視光領域における色については, 白色
光がより効果的に成虫を誘引した。また, 同一白色光で は照度の高い電球ほどより効果的に成虫を誘引した。す なわち, 可視光領域においては光質よりも, 光量が成虫 を集める重要な要因となっていることが示唆され, 強光 による成虫の誘引が可能であることが明らかとなった。

3．幼虫，ないしは蛹の制御実験として,「網いけす」 を用いた魚類の捕食実験を行った。高密度にコイを投入 した実験区Aでは，いけす外(実験区 C)，および魚を除 いた実験区 $\mathrm{B}$ に対し，有意にユスリカの発生量は減少し た。実験期間中の各実験区における成虫の発生量から, コイの高密度投入によっては，底泥から羽化するユスリ カの約 $58 \%$ が除去され，また，現在の諏訪湖の魚類密度 でも38\%が除去されることが推定された。以上の事から コイをはじめとする魚類による幼虫除去は有効な対策の 一つと考元られる。

4. 本研究で明らかとなったことを基に, 諏訪湖地域 をモデルとして，ユスリカ大量発生に対する対策を提言 する。

（1）ユスリカ羽化の事前予知と情報の徹底：ユスリカ 生活環，および成長要因の解明をさらに進める。

(2) 光の配置の再検討 : 成虫の誘引・捕獲のための強 光の配置，および住民の生活圏への飛来を防止するため の光の配置を考慮した町づくりを検討する。

（3）沿岸生態系の回復：近年減少傾向が認められるコ イ,フナなどの生活・繁殖場所としての沿岸生態系を回 復させ，捕食者とのバランスをとる。このことは，成虫 の捕食者ともなる昆虫類, 鳥類の生活圏の確保にもなり, さらに，人間とユスリカの生活圏の分離のためにも役立 つ。

（4）湖への栄養塩類負荷の減少：ユスリカへの餌の供 給を減少させ, 現存量を減少させる。これは, 富栄養化 抑制の努力と一致する。

\section{謝辞}

本研究の遂行にあたり，御指導いただいた信州大学医 学部村山忍三教授に深く感謝します。また御指導御助言 をいただいた信州大学理学部沖野外輝夫博士，林秀剛博 士，信州大学医学部那須裕博士に厚く御礼申し上げます。 気象デー夕を心良く提供してくださった信州大学教養部 環境科学研究室の星川和俊博士に感謝致します。調査を 行うにあたり，塩野崎寛氏，中里亮治氏（信大諏訪臨湖 実験所)，大前浩美氏，伝田郁夫氏（長野県水産試験 場), 東芝ライテック（株）の品田氏，王瑞生氏（信大医 学部）に協力していただいた。この場をお借りしてお礼 
を申し上げます。

本研究は, 平成 2 年度文部省科学研究費奨励研究・特 (Grant No. 02954147) の補助を受けて行われた。 本研究の一部は, 第60回日本衛生学会総会 $(1990)$, 第 61回日本衛生学会総会（1991）にて発表された。

\section{文献}

1) Iwakuma, T. and Yasuno, M. : Chironomid population in highly eutrophic Lake Kasumigaura, Verh. Internat. Verein. Limnol., 21, 664-674 (1981).

2) Yamagishi, H. and Fukuhara, H.: Ecological studies on Chironomids in Lake Suwa, 1. Population dynamics of two large Chronomids, Chir. onomus plumosus L. and Spaniotoma akamusi Tokunaga, Oecologia, 7, 309-327 (1971).

3) 三浦 正：ユスリカ主要種とその発生消長について (中海及び宍道湖の水生昆虫相に関する研究 2 ), 島 大農研報, 12，41-45（1978）。

4）清水憲一：神田川に扔けるユスリカについて, 生活 と環境, 23, 25-38 (1978).

5）井上義郷：不快昆虫としてのユスリカ，環境衛生， 22, 6-12 (1975).

6）井上義郷：水域環境の変化とユスリカ，遺伝， 30 , 25-31 (1976).

7）三原 実, 井上義郷：我が国における不快害虫とし てのユスリカに関する研究，2．東京神田川におけ るセスジュスリカ成虫の発生消長, 衛生動物, 28 , 431-437 (1977).

8）村上巧啓, 五十嵐隆夫, 佐伯陽子, 足立雄一, 松野 正知, 岡田敏夫, 河合幸一郎, 熊谷 朗, 佐々 学: ユスリカ喘息に関する研究，アレルギー，35，395401 (1986).

9) Kawai, K. and Konishi, K. : Fundamental studies on Chironomid allergy-2. Analysis of larval allergens of some Japanese Chironomids (Chironomidae, Diptera) -, Allergy, 35, 1088-1098 (1986).

10) Ito, K., Miyamoto, T., Shibuya, T., Kamei, K., Mano, K., Taniai, T. and Sasa, M. : Skin test and radioallergosorbent test with extracts of larval and adult midges of Tokunagayusurika akamusi Tokunaga (Diptera: Chironomidae) in asthmatic patients of the metropolitan area of
Tokyo, Annals of Allergy, 57, 199-204 (1986).

11) Matsuoka, H., Ishii, A., Kimura, Y. and Noono, S. : Developmental change of Chironomid allergen during metamorphosis, Allergy, 45, 115-120 (1990).

12) Kimura, H., Matsuoka, H. and Ishii, A. : ELISA inhibition method in detection of mite and Chironomid antigens in environmental samples of dust, soil and air, Allergy, 45, 167-173 (1990).

13）井上義郷：ユスリカの駆除対策, 生活と環境, 22, 74-79 (1977).

14）池本孝哉, 宮崎道雄, 渋谷敏朗 : 東京都内のユスリ 力発生とその対策, 環境衛生，32，20-25（1986).

15）林 晃史：都市型害虫とその管理一蚊でない力の防 除一, 環境衛生, 36, 20-25 (1990).

16) Ali, A.: Nuisance Chironomids and their control : a review, Bull. Entomol. Soc. Am., 26, 3-16 (1980).

17) Tabaru, Y., Moriya, K. and Ali, A.: Nuisance midges (Diptera : Chironomidae) and their control in Japan, J. Amer. Mosquito Control Association, 3, 45-49 (1987).

18）佐藤英毅, 安野正之：数種ユスリカの殺虫剤感受性 試験，衛生動物，30，361-366（1979）。

19）田原雄一郎：本邦における昆虫成長制御剂（ジフル ベンズロン）の衛生害虫駆除分野における評価, 生 活と環境, 33, 77-81 (1988).

20）田原雄一郎：都市河川の污染とセスジュスリカの大 量発生並びにその薬剤防除の試み, 衛生動物, 26, 247-251 (1975).

21）田原雄一郎，松永秀子，佐藤淳夫：都市河川におけ るセスジュスリカの薬剤防除, 特に有効水域と流失 幼虫の生死について, 衛生動物, 29, 87-91 (1978).

22）大倉 正, 田原雄一郎：養鰻池から発生するユスリ 力の防除に関する研究, 水産増殖, 23, 1-7 (1975).

23) Yasuno, M., Hasegawa, J., Iwakuma, T., Imamura, N. and Sugaya, Y.: Effects of temephos on chironomid and plankton populations in eel culture ponds, Jpn. J. Sanit. Zool., 33, 207-212 (1982).

24）圓谷哲男, 森 忠洋, 松本利通：下水処理場におけ るユスリカ (Chironomus yoshimatsui) の生態とそ の発生防止. 1. 実態調查及びユスリカのライフサ 
イクル，用水と排水，24，69-73（1982 a ）。

25）圓谷哲男, 森谷清樹, 森 忠洋, 松本利通: 下水処 理場におけるユスリカ (Chironomus yoshimatsui) の生態とその発生防止. 2 . 薬剤によるユスリカ発 生防止，用水と排水， 24，20-26（1982 b ).

26) Mulla, M.S. Norland, R.L. Westlake, W.E. Dell, B. and Amant, J.S.: Aquatic midge larvicides, their efficacy and residues in water, soil, and fish in a warm-water lake, Environmental Ent., 2, 5865 (1973).

27）平林公男：諏訪湖地域における “迷惑昆虫”ユスリ カの大発生とその防除対策一第 1 報：アカムシュス リカ (Tokunagayusurika akamusi) 成虫の大量飛来 一, 日衛誌, 46, 652-661 (1991).

28）平林公男：諏訪湖地域における “迷惑昆虫”ユスリ カの大発生とその防除対策一第 2 報：ユスリカ問題 に対する住民の意識構造とその数量化の試み一, 日 衛誌, 46, 662-675 (1991).

29）山岸 宏, 福原晴夫：諏訪湖のユスリカについて, JIBP - PF 諏訪湖生物群集の生産力研究, 46-59 (1969).

30) Iwakuma, T. and Yasuno, M.: Fate of the univoltine chironomid, Tokunagayusurika akamusi (Diptera : Chironomidae), et emergence in Lake Kasumigaura, Japan, Arch. Hydrobiol., 99, 37-59 (1983).

31) Iwakuma, T., Sugaya, Y. and Yasuno, M. : Dependence of the autumn emergence of $T o$ kunagayusurika akamusi (Diptera: Chironomidae) on water temperature, Jpn. J. Limno., 50, 281-288 (1989).

32）大滝哲也：幼若ホルモン殺虫剤，環境衛生，22，611 (1976).

33) Ali, A. and Jeffery, L.: Experimental Insect Growth Regulators against some nuisance Chironomid midges of Central Florida, J. Econ. Entomol. 73, 243-249 (1980).

34) Ohba, M. and Aizawa, K. : Insaeect toxicity of Bacillus thuringiensis isolated from soils of Japan, J. Invertebr. Pathol., 47, 12-20 (1986).

35) Krieg, A. and Laugenbruch, G.A. : Susceptibility of arthropod species to Bacillus thuringiensis., In "Microbial Control of Pests and Plant diseases 1975-1980" ed. by H.D. Burges, pp. 837-896, Aca- demic Press, New York (1981).

36) Ali, A. : Bacillus thuringiensis serovar. israelensis (ABG-6108) against Chironomids and some nontarget aquatic invertebrates, J. Invertebr. Pathol., 38, 264-272 (1981).

37) Ali, A., Richard, D.B. and Jonas, P.S. : Susceptibility of some Florida Chironomids and Mosquitoes to various formulations of Bacillus thuringiensis serovar. israelensis, J. Econ. Entomol. 74, 672-677 (1981).

38）岩熊敏夫, 安田 香, 平林公男, 林 秀剛：カワチ ブナ投入によるメソコスム内の底生動物群集変動と ユスリカ羽化量, 文部省科学研究費特定研究 “メソ コスムによる水域生物相互作用系の実験的解析”105 -108 (1986).

39）岩熊敏夫, 花里孝幸, 安田 香, 林 秀剛, 平林公 男, 大前浩美：ペリアジ投入によるメソコスム内の 底生動物群集変動及びュスリカ羽化期・羽化期以降 におけるペリアジの食性変化, 文部省科学研究費特 定研究 “メソコスムによる水域生物相互作用系の実 験的解析”, 109-113 (1986).

40）岩熊敏夫，花里孝幸，林 秀剛，平林公男，安田郁 子, 安田 香, 山本熔子, 菅野徳彦, 渡辺泰徳: メ ソコスムへの冷水魚コレゴナス (Coregonus lavar. etus maraena）投入による水界生態系攪乱と生物相 互作用, 文部省科学研究費特定研究 “メソコスムに よる水域生物相互作用系の実験的解析”，126-144 (1988).

41）平出 保, 沖野外輝夫：諏訪湖湖内の有機物収支に 及ぼすユスリカの影響, 諏訪湖集水域生態系研究, 9, 31-44 (1983).

42）藤山静雄：灯火による昆虫の誘引の問題点と対策, 道路と自然，49，26-31（1985）。

43) Magnum, C.L. and Callahan, P.S. : Attraction of near-infrared radiation to Aedes aegypti (Linnaeus), J. Econ. Entomol., 61, 36-37 (1968)

44) Williams, C.B. and Davis, L. : Simuliidae attracted at night to a trup ultraviolet light, Nature (London), 179, 924-925 (1951).

45) Glick, P.A. and Hollingsworth, J.P. : Response of the pink bollworm moth to certain ultraviolet and visible radiation, J. Ecoc. Entomol., 47, 81-86 (1954).

46) Barr, A.R. and Boreham, M.M. : Light intensity 
and the attraction of mosquitoes to light traps, J. Econ. Entomol., 53, 876-880 (1967).

47) Belton, P. and Pucat, A. : A comparison of different lights in traps for Culicoides (Diptera : Ceratopogonidae), Can. Entomol., 99, 267-272 (1967).

48) Ali, A. Stafford, S.R. Fowler, R.C. and Stanley, B. H. : Attraction of adult Chironomidae (Diptera) to incandescent light under laboratory condition, Environ. Entomol., 13, 1004-1009 (1984).

49) Ali, A. Stanley, B.H. and Chaudhuri, P.K.:
Attraction of some adult midges (Diptera : Chir onomidae) of Florida to artificial light in the field, Florida Entomol., 69, 644-650 (1986).

50) Iwakuma, T. and M. Yasuno.: The role of zoobenthos a shallow eutrophic lake., Arch. Hydrobiol. Beih., 28, 515-524 (1987).

51）沖野外輝夫：地域研究としての諏訪湖集水域生態系 研究，環境科学，1，83-89 (1988).

（受付 1990年11月19日 受理 1991年 2 月 8 日） 